\title{
Evaluation of treatment of previous cesarean scar pregnancy with methotrexate: a systematic review and meta-analysis
}

Nader Salari ${ }^{1,2}$, Mohsen Kazeminia ${ }^{3}$, Shamarina Shohaimi ${ }^{4}$, Anis al-Dawlah Nankali ${ }^{5}$ and Masoud Mohammadi ${ }^{6 *}$ (I)

\begin{abstract}
Background: Previous caesarean scar pregnancy is one type of ectopic pregnancy in myometrium and fibrous tissue of previous caesarean scar. One of the therapeutic methods of this type of ectopic pregnancy is treatment with methotrexate. Given various findings on the treatment of caesarean scar pregnancy with methotrexate and lack of global report in this regard, we aimed to achieve a global report on the treatment of CSP with methotrexate through related literature review and analysis of the results of the studies, to enable more precise planning to reduce complications of CSP.

Method: This review study extracted information through searching national and international databases of SID Embase, ScienceDirect, Scopus, PubMed, Web of Science (ISI) between 2003 and January 2020. To perform the meta-analysis, random-effects model and heterogeneity of the studies with $\mathrm{I}^{2}$ index were investigated. Data were sanalysed using Comprehensive Meta-Analysis version 2.
\end{abstract}

Results: In total, 26 articles with a sample size of 600 individuals were enrolled in the meta-analysis. According to the results of the study, the mean level of $\beta$-hCG was $28,744.98 \pm 4425.1 \mathrm{mlU} / \mathrm{ml}$ before the intervention and was $23,836.78 \pm 4533.1 \mathrm{mlU} / \mathrm{ml}$ after the intervention. The mean intraoperative blood loss (ml) was $4.8 \pm 3.76 \mathrm{ml}$, mean hospital stay (days) was $11.7 \pm 1.2$ days, mean time for serum-hCG normalization (days) was $41.6 \pm 3.2$ days, success was $90.7 \%$ (95\% Cl: 86.7-93.5\%), and complication was 9\% (95\% Cl: 6.3-12.8\%).

Conclusion: The results of the current study show methotrexate significantly reduces $\beta$-hCG levels and can be effective in treating caesarean scar pregnancy and its complications.

Keywords: Caesarean scar pregnancy, CSP, MTX, Methotrexate, Meta-analysis

\footnotetext{
* Correspondence: Masoud.mohammadi1989@yahoo.com

${ }^{6}$ Department of Nursing, School of Nursing and Midwifery, Kermanshah University of Medical Sciences, Kermanshah, Iran

Full list of author information is available at the end of the article
}

(c) The Author(s). 2020 Open Access This article is licensed under a Creative Commons Attribution 4.0 International License, which permits use, sharing, adaptation, distribution and reproduction in any medium or format, as long as you give appropriate credit to the original author(s) and the source, provide a link to the Creative Commons licence, and indicate if changes were made. The images or other third party material in this article are included in the article's Creative Commons licence, unless indicated otherwise in a credit line to the material. If material is not included in the article's Creative Commons licence and your intended use is not permitted by statutory regulation or exceeds the permitted use, you will need to obtain permission directly from the copyright holder. To view a copy of this licence, visit http://creativecommons.org/licenses/by/4.0/. The Creative Commons Public Domain Dedication waiver (http://creativecommons.org/publicdomain/zero/1.0/) applies to the data made available in this article, unless otherwise stated in a credit line to the data. 


\section{Background}

Ectopic pregnancy refers to pregnancies which occur out of uterus cavity and $98 \%$ of cases occur in the fallopian tube while another $2 \%$ occur in uncommon places such as the ovary, abdomen, caesarean scar and other [1]. The prevalence of ectopic pregnancies has increased from $0.5 \%$ in the last four decades to $2 \%$ in recent decades [1-3]. The rRupture of ectopic pregnancies leads to a high rate of mortality in mothers [4].

Ectopic pregnancy can also cause life-threatening bleeding which needs immediate medical care.

An ectopic pregnancy usually occurs within the first few weeks of pregnancy. Early signs of an ectopic pregnancy include light vaginal bleeding and pelvic pain, upset stomach and vomiting, sharp abdominal cramps, pain on one side of your body, dizziness or weakness, pain in the shoulders, neck, or rectum [1-4].

However, diagnostic methods such as intrauterine sonography, measuring $\beta$-hCG level provide context to implement early therapeutic interventions through considerably reducing prevalence of rupture in ectopic pregnancies and mortality cases [2].

Caesarean scar pregnancy (CSP) is one type of ectopic pregnancies in myometrium and fibrous texture of the previous caesarean scar. The reported rate varies from 1 per 1800 to 1 per 2216 pregnancies. The rate of ectopic pregnancies with one to two caesareans is $6.1 \%[5,6]$.

Factors which affect the selection of therapeutic method include gestational age, the tendency for future pregnancy, and present facilities, and therapeutic options such as medicinal treatment, or laparoscopy surgery and laparotomy, sembolisation of uterus artery, injection of potassium chloride, and intra-gestational sac methotrexate [7].

Pharmaceutical treatment is preferred by patients rather than surgery and is an appropriate substitute for surgical therapy because it also reduces treatment costs [7].

Pharmaceutical therapeutic method used mostly in the treatment of ectopic pregnancies is using a single dose of methotrexate and redosing if needed [8].

Methotrexate is an inhibitor of folic acid synthesis, and the inhibition of new purines and pyrimidines leads to the disturbing synthesis of DNA and cell proliferation. These effects appear especially in tissues with high cell turnover, such as pregnancy products [9].

However, various studies have reported between 22 and $48 \%$ of failure in the treatment process for this therapeutic regimen [10-14].

Improvement of the efficacy of treatment can prevent serious risks such as the rupture of tubes and intraabdominal bleeding which may lead to failure in treatment and subsequently a decline in the number of surgeries, days of hospitalisation, and cost of treatment,
Two approaches can be considered;firstly, pharmaceutical treatment at a low serum level of $\beta$-hCG, and progesterone with a small size of gestational sac without heart rate can be initiated. The second approach is an increase in the efficacy of methotrexate regimen and using a pharmaceutical combination of methotrexate with other medication [9].

Given various findings on the treatment of caesarean scar pregnancy with methotrexate and lack of global report in this regard, we aimed to achieve a global report on the treatment of CSP with methotrexate through related literature review and analysis of the results of the studies, to enable more precise planning to reduce complications of CSP.

\section{Methods}

This systematic review and meta-analysis investigated the treatment of CSP with methotrexate based on studies conducted from 2003 to January 2020. Thereby, published articles in national and international databases of SID Embase ScienceDirect Scopus PubMed, and Web of Science (ISI) by keywords of cesarean scar pregnancy, CSP, Methotrexate, and MTX were reviewed.

In this study, the AND/OR operators were used to provide more comprehensive access to all articles. Therefore, the AND/OR operator was used to check the common names for the disorder by matching words in the MeSH browser.

$((()(()(()(()((($ Pregnancy [Title/Abstract] $)$ OR (Maternal-Fetal Relations [Title/Abstract])) OR (Pregnant Women [Title/Abstract])) OR (Pseudopregnancy [Title/ Abstract])) OR (Prenatal Care [Title/Abstract])) AND (cesarean [Title/Abstract])) AND (scar [Title/Abstract])) OR (Cicatrix [Title/Abstract])) OR (Scarring [Title/Abstract])) OR (Scars [Title/Abstract])) OR (CSP [Title/Abstract])) AND (Methotrexate [Title/Abstract])) OR (Amethopterin [Title/Abstract])) OR (Methotrexate Hydrate [Title/Abstract])) OR (Methotrexate Sodium [Title/Abstract])) OR (Methotrexate, (D)-Isomer [Title/ Abstract])) OR (Methotrexate, Sodium Salt [Title/Abstract])) OR (Methotrexate, (DL)-Isomer [Title/Abstract])) OR (MTX [Title/Abstract]))))))))

The inclusion criteria to select articles were as follow observational studies (non-interventional studies) and accessibility of the full text. In order to obtain more information, references for the relevant articles were reviewed to access to other articles.

\section{Selection of articles}

At first, all the articles on the treatment of CSP with methotrexate were gathered by researchers and the eligible articles were included based on the inclusion and exclusion criteria. Exclusion criteria include irrelevant 
articles, duplicates, ambiguity in materials and methods, and lack of access to full-texts.

To control for bias, the literature review was performed by two independent researchers, and in case of disagreement, the article was referred to the supervisor to be reviewed. Finally, 35 articles were entered in the third phase of qualitative assessment.

Articles derived from observational studies were included while review, case-control, cohort, and interventional studies were excluded from the list of articles. Duplicate publications and multiple publications from the same population were removed using citation management software EndNote (version X7, for Windows, Thomson Reuters).

\section{Qualitative assessments of articles}

The CONSORT checklist was used to evaluate the quality of articles. This checklist consists of the design, background, literature review, location and time of study, outcome, inclusion criteria, sample size and statistical analysis. Articles with scores in 6-7 items were considered as high-quality articles while articles which had between two to seven items and two items were considered as articles with moderate and low quality, respectively [15].

In the current study, 26 high and moderate-quality articles were entered in the systematic review and metaanalysis while 9 low-quality articles were excluded.

\section{Data extraction}

All the final articles entered in the meta-analysis were extracted using a pre-prepared check-list. The checklist includes article title, first author, year of publication, study location, sample size, the mean level of $\beta$-hCG, intraoperative blood loss (ml), hospital stay (days), time for serum-hCG snormalisation (days), success percentage, complication percentage and methods.

\section{Data analysis}

To assess heterogeneity of enrolled studies, the $\mathrm{I}^{2}$ index was used, and meta regression analysis was used to investigate the association between mean level of $\beta$-hCG, year of publication and sample size and the probability of publication bias in results was measured using the funnel plot, the Egger test and the significance level of 0.05 . To assess the effect of each study individually on the final outcome, sensitivity test was used. Analysis of data was performed using Comprehensive Meta-Analysis Software (Version 2).

\section{Results}

In this study, all studies on the treatment of CSP with methotrexate without time limitation and based on PRIS MA guideline were assessed systematically. In primary searching, 1040 articles were identified, which finally, 26 articles published between 2003 and January 2020 were entered in the final analysis (Fig. 1) (Table 1).

\section{Publication bias}

The publication bias in results of intraoperative blood loss (ml) by funnel plot and Egger test at significance level of 0.05 indicate the lack of bias in publication in the current study $(P=0.06)$ (Fig. 2$)$.

The publication bias in results of hospital stay (days) by funnel plot and Egger test at significance level of 0.05 indicates lack of bias in publication in the current study $(P=0.269)$ (Fig. 3).

The publication bias in results of time for serum-hCG snormalisation (days) by funnel plot and Egger test at significance level of 0.05 indicates lack of bias in publication in the current study ( $P=0.095)$ (Fig. 4).

The publication bias in results of success by funnel plot and Egger test at significance level of 0.05 indicates lack of bias in publication in the current study $(P=$ 0.082) (Fig. 5).

The publication bias in results of complication by funnel plot and Egger test at significance level of 0.05 indicates lack of bias in publication in the current study $(P=0.07)$ (Fig. 6).

\section{Heterogeneity}

According to results obtained from the test $\left(\mathrm{I}^{2}: 100\right),\left(\mathrm{I}^{2}\right.$ : 100), $\left(I^{2}: 98.2\right),\left(I^{2}: 98\right),\left(I^{2}: 97.8\right)$, and $\left(I^{2}: 29.7\right)$ and due to the heterogeneity of selected studies, random effect model to combine studies and a common estimate of the mean level of $\beta$-hCG before and after the intervention, intraoperative blood loss (ml), hHospital stay (days), time for serum-hCG snormalisation (days), success percentage, and complication percentage were used.

The total sample size was 600 individuals and the characteristics of selected articles are presented in Table 1.

Out of 26 articles entered the meta-analysis, 17 articles were for methotrexate alone, 3 articles were on MTX + D\&C, three articles were on UAE + MTX, and three articles were on MTX-curettage.

According to results of the study, the mean level of $\beta$ hCG was $28,744.98 \pm 4425.1 \mathrm{mIU} / \mathrm{ml}$ before the intervention and $23,836.78 \pm 4533.1 \mathrm{mIU} / \mathrm{ml}$ after the intervention, which shows the reducing effect of the drug on patients (Figs. 7 and 8).

According to the results of the study, mean intraoperative blood loss (ml) was $76.3 \pm 8.4 \mathrm{ml}$ (Fig. 9).

According to the results of the study, mean hospital stay (days) was $11.7 \pm 1.2$ days (Fig. 10).

According to the results of the study, time for serumhCG snormalisation (days) was $41.6 \pm 3.2$ days (Fig. 11).

According to the results of the study, success percentage was 90.7\% (95\% CI: 86.7-93.5\%) (Fig. 12). 
1040 potentially relevant studies identified and screened (SID: 68, PubMed: 424, ScienceDirect: 107, Scopus: 200, ISI: 69 , Embase: 172)

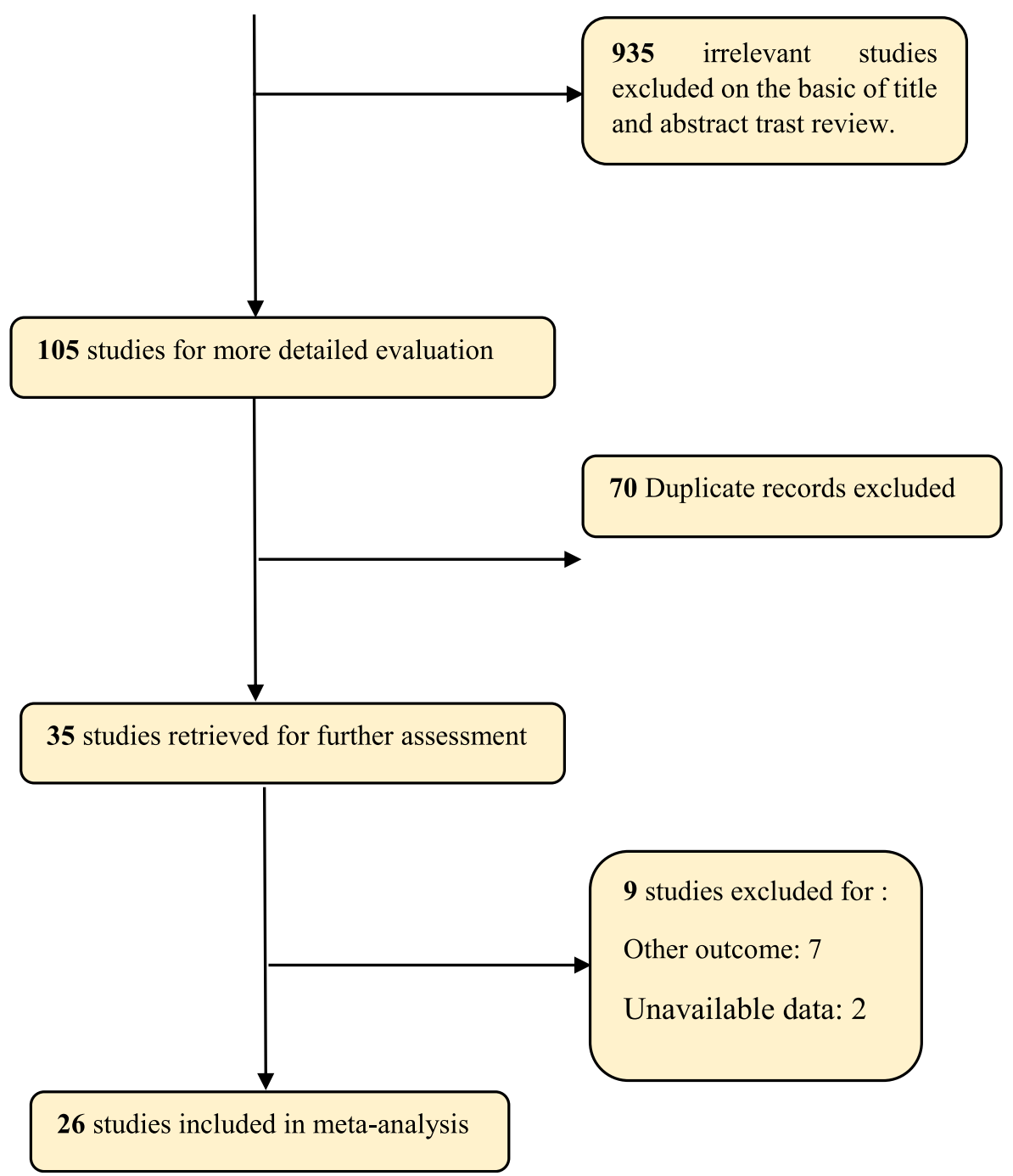

Fig. 1 Flow diagram of study selection

According to the results of the study, complication percentage was 9\% (95\% CI: 6.3-12.8\%) (Fig. 13).

\section{Discussion}

This study aimed to determine the treatment of CSP with methotrexate through a systematic review and meta-analysis.

According to findings of this study, mean level of $\beta$ hCG before the intervention was 28,744.98 \pm 4425.1 $\mathrm{mIU} / \mathrm{ml}$ and was $23,836.78 \pm 4533.1 \mathrm{mIU} / \mathrm{ml}$ after the intervention, which indicates methotrexate considerably decreases the $\beta$-hCG level.

In addition, time for serum-hCG snormalisation was $41.6 \pm 3.2$ days. Methotrexate, a folic acid antagonist by deactivating dihydrofolate reductase enzyme, depletes the available reservoir of tetrahydrofolate, and tissues with high-turnover such as trophoblasts are particularly vulnerable to this medication. Treatment with methotrexate reduces the speed of increasing $\beta$-hCG [39]. Single-dose, double dose and multidose therapeutic regimens of methotrexate are recommended. 
Table 1 Characteristics of meta-analysis studies

\begin{tabular}{|c|c|c|c|c|c|c|}
\hline Author, year, Reference & Country & $\begin{array}{l}\text { Sample } \\
\text { size }\end{array}$ & $\begin{array}{l}\beta \text {-hCG level } \\
(\mathrm{mlU} / \mathrm{ml})\end{array}$ & Methods of intervention & Characteristic & Quality \\
\hline Wang-1, 2018, [16] & China & 46 & $\begin{array}{l}\text { Before }=44,603.28 \\
\text { After }=37,712.91\end{array}$ & $\begin{array}{l}50 \mathrm{mg} / \mathrm{m}^{2} \text { intramuscularly } \\
\text { two times (Day } 0 \text { and } \\
\text { Day 4) MTX }\end{array}$ & $\begin{array}{l}\text { Age } \text { (years) }=31.15 \pm 5.59 \\
\text { Intraoperative blood loss }(\mathrm{ml})=55.33 \pm 44.19 \\
\text { Hospital stay }(\text { days })=9.59 \pm 2.46 \\
\text { Gestational age }(\text { day) }=48.96 \pm 8.27 \\
\text { Number of cesarean deliveries }=1.17 \pm 0.383 \\
\text { Fetal heart beat positive, } n=21\end{array}$ & High \\
\hline Wang-2, 2018, [16] & China & 14 & $\begin{array}{l}\text { Before }=25,648.86 \\
\text { After }=31,005.21\end{array}$ & $\begin{array}{l}\text { intravenously for } 5 \text { days } \\
\text { (Day } 0 \text { to Day 5) MTX }\end{array}$ & $\begin{array}{l}\text { Age (years) }=34.14 \pm 4.86 \\
\text { Intraoperative blood loss }(\mathrm{ml})=42.86 \pm 22.68 \\
\text { Hospital stay (days) }=13.86 \pm 3.88 \\
\text { Gestational age (day) }=52.15 \pm 7.94 \\
\text { Number of cesarean deliveries }=1.57 \pm 0.514 \\
\text { Fetal heart beat positive, } n=5\end{array}$ & High \\
\hline Giampaolino, 2018, [17] & Italy & 19 & $\begin{array}{l}\text { Before }=1790 \\
\text { After }=35,034\end{array}$ & $\begin{array}{l}50 \mathrm{mg} / \mathrm{m}^{2} \text { intramuscularly } \\
\text { One times MTX+ D\&C }\end{array}$ & $\begin{array}{l}\text { Age (years) }=32.68 \pm 3.92 \\
\text { Gestational age (day) }=50.47 \pm 4.43 \\
\text { Complication, } n=0\end{array}$ & High \\
\hline Jiang, 2011, [18] & China & 45 & After $=28,717$ & $\begin{array}{l}50 \mathrm{mg} / \mathrm{m}^{2} \text { intramuscularly } \\
\text { One times MTX }\end{array}$ & $\begin{array}{l}\text { Age (years) }=34.46 \pm 5.19 \\
\text { Intraoperative blood loss }(\mathrm{ml})=706.89 \pm 642.08 \\
\text { Time for serum-hCG normalization (days) }=20.62 \pm 5.41 \\
\text { Complication, } n=3 \\
\text { Success } \%=93.3\end{array}$ & High \\
\hline Shen, 2012, [19] & China & 46 & & $\begin{array}{l}\text { intravascularly One times } \\
\text { MTX }\end{array}$ & $\begin{array}{l}\text { Age (years) }=32.7 \pm 6.0 \\
\text { Hospital stay (days) }=10.5 \pm 1.0 \\
\text { Time for serum-hCG normalization (days) }=37.7 \pm 4.8 \\
\text { Time for CSP mass disappearance (days) }=33.3 \pm 4.3 \\
\text { Gestational age (day) }=55.5 \pm 2.4 \\
\text { Complication, } n=1 \\
\text { Success } \%=97.8\end{array}$ & High \\
\hline
\end{tabular}

$\begin{array}{lllll}\text { Qi, 2015, [20] China } & 22 & \text { After }=45,710 & \begin{array}{l}\text { UAE }+ \text { MTX }+50 \mathrm{mg} / \mathrm{m}^{2} \\ \text { Intramuscular }\end{array} \\ \text { Gao, 2014, [21] } & \text { China } & 119 & \begin{array}{l}\text { Before }=45,321.50 \\ \text { After }=43,586\end{array} & \begin{array}{l}\text { D\&C }+ \text { MTX }+50 \mathrm{mg} / \mathrm{m}^{2} \\ \text { Intramuscular }\end{array}\end{array}$

Intraoperative blood loss $(\mathrm{ml})=80.25 \pm 113.92$

Time for serum-hCG normalization (days) $=31.18 \pm 14.80$

Gestational age $($ day $)=59.86 \pm 17.67$

Complication, $n=4$

Success $\%=77.3$

Liu, 2016, [22] China 26 $\begin{array}{ll}\text { Before }=8242 & \begin{array}{l}\text { MTX-curettage }+ \\ \text { After }=\end{array} \\ & \text { Intramuscular (50 mg } / \mathrm{m}^{2} \\ \text { body surface area) }\end{array}$

Cao, 2018, [23] China $36 \quad \begin{aligned} & \text { UAE }+ \text { MTX }+40 \mathrm{mg} / \mathrm{m}^{2} \\ & \text { Intramuscular }\end{aligned}$

Feng, 2016, [24]

China

11

Sevket, 2014, [25]

Turkey

11

Fadhlaoui, 2012, [26]

Intramuscular
Intraoperative blood loss $(\mathrm{ml})=261.0 \pm 357.4$

Hospital stay (days) $=14.6 \pm 9.2$

Time for serum-hCG normalization (days) $=40.5 \pm 17.2$

Gestational age (day) $=48.4 \pm 7.6$

Number of cesarean deliveries $=1.2 \pm 0.4$

Fetal heart beat positive, $n=8$

Complication, $n=10$

Success $\%=91.6$

Gravidity $=3.9 \pm 1.6$

Parity $=1.4 \pm 0.6$

Age (years) $=31.82 \pm 4.80$

Intraoperative blood loss $(\mathrm{ml})=335$

Hospital stay (days) $=19.38$

Time for serum-hCG normalization (days) $=56.15 \pm 15.99$

Gestational age (day) $=48.4 \pm 7.6$

Fetal heart beat positive, $n=8$

Complication, $n=4$

Success $\%=84.6$

Age (years) $=33.46 \pm 4.47$

Intraoperative blood loss $(\mathrm{ml})=11.44 \pm 4.87$

Hospital stay (days) $=5.39 \pm 1.02$

Time for serum-hCG normalization (days) $=34$

Complication, $n=3$

Success $\%=91.7$

Age (years) $=32.20 \pm 4.83$

Intraoperative blood loss $(\mathrm{ml})=16 \pm 3.8$

High

Time for serum-hCG normalization (days) $=27$

Complication, $n=0$

Success $\%=95.8$

Hospital stay $($ days $)=14.45 \pm 4.96$

Complication, $n=0$

Success $\%=95.8$

Age (years) $=35$

Hospital stay (days) $=8$

High

Time for serum-hCG normalization (days) $=34$ two times (Day 0 and Day 4) MTX 
Table 1 Characteristics of meta-analysis studies (Continued)

\begin{tabular}{|c|c|c|c|c|c|c|}
\hline Author, year, Reference & Country & $\begin{array}{l}\text { Sample } \\
\text { size }\end{array}$ & $\begin{array}{l}\beta \text {-hCG level } \\
(\mathrm{mlU} / \mathrm{ml})\end{array}$ & Methods of intervention & Characteristic & Quality \\
\hline Wang, 2009, [27] & China & 21 & After $=13,576$ & $\mathrm{D} \& \mathrm{C}+\mathrm{MTX}+$ Intramuscular & $\begin{array}{l}\text { Age }(\text { years) }=33.4 \pm 4.8 \\
\text { Time for serum-hCG normalization (days) }=38 \\
\text { Complication, } n=5 \\
\text { Success } \%=76.2\end{array}$ & High \\
\hline Abdelazim, 2017, [28] & Kazakhstan & 1 & & $\begin{array}{l}\text { Multi-dose MTX+ } \\
\text { Intramuscular }\end{array}$ & $\begin{array}{l}\text { Age }(\text { years })=37 \\
\text { Hospital stay (days) }=4 \\
\text { Fetal heart beat positive, } n=8 \\
\text { Complication, } n=0\end{array}$ & High \\
\hline Uludag-1, 2016, [29] & Turkey & 17 & $\begin{array}{l}\text { Before }=27,970 \\
\text { After }=11,010\end{array}$ & $\begin{array}{l}\text { local methotrexate } \\
\text { injection }\end{array}$ & $\begin{array}{l}\text { Age }(\text { years })=32.76 \pm 5.25 \\
\text { Hospital stay }(\text { days })=7.05 \pm 2.77 \\
\text { Complication, } n=0 \\
\text { Success } \%=97.2\end{array}$ & High \\
\hline Uludag-2, 2016, [29] & Turkey & 27 & $\begin{array}{l}\text { Before }=7606 \\
\text { After }=4725\end{array}$ & systemic methotrexate & $\begin{array}{l}\text { Age (years) }=31.07 \pm 4.17 \\
\text { Hospital stay (days) }=11.96 \pm 4.02 \\
\text { Complication, } n=0 \\
\text { Success } \%=98.2\end{array}$ & High \\
\hline Ko, 2015, [30] & China & 10 & Before $=50,666$ & intralesional methotrexate & $\begin{array}{l}\text { Age (years) }=34.9 \pm 4.8 \\
\text { Complication, } n=2 \\
\text { Success } \%=80.0\end{array}$ & High \\
\hline Yin, 2014, [31] & China & 22 & $\begin{array}{l}\text { Before }=40,154.17 \\
\text { After }=2531.56\end{array}$ & $\begin{array}{l}\text { intramuscularly two times } \\
\text { (Day } 0 \text { and Day 4) MTX }\end{array}$ & $\begin{array}{l}\text { Age (years) }=28.5 \pm 3.9 \\
\text { Intraoperative blood loss }(\mathrm{ml})=139 \pm 4.83 \\
\text { Hospital stay (days) }=25 \pm 6.61 \\
\text { Gestational age (day) }=56.14 \pm 21.12 \\
\text { Complication, } n=1 \\
\text { Success\% }=95.5\end{array}$ & High \\
\hline Cok, 2015, [32] & Turkey & 18 & Before $=12,699$ & local methotrexate injection & $\begin{array}{l}\text { Age (years) }=33.7 \pm 3.4 \\
\text { Complication, } n=3 \\
\text { Success } \%=83.3\end{array}$ & High \\
\hline Timor-Tritsch, 2015, [33] & USA & 33 & & $\begin{array}{l}\mathrm{MTX}+50 \mathrm{mg} / \mathrm{m}^{2} \\
\text { Intramuscular }\end{array}$ & $\begin{array}{l}\text { Complication, } n=1 \\
\text { Success } \%=93.9\end{array}$ & Medium \\
\hline Yamaguchi, 2014, [34] & Japan & 8 & Before $=45,823$ & local MTX injection & $\begin{array}{l}\text { Age }(\text { years })=32.3 \pm 4.1 \\
\text { Time for serum-hCG normalization (days) }=78.5 \\
\text { Complication, } n=0 \\
\text { Success } \%=94.4\end{array}$ & High \\
\hline Seow, 2013, [35] & China & 11 & $\begin{array}{l}\text { Before }=20,520 \\
\text { After }=22,500\end{array}$ & $\begin{array}{l}\text { One injection of } \\
\text { Intramuscular MTX }\end{array}$ & $\begin{array}{l}\text { Age }(\text { years })=33.8 \pm 4.0 \\
\text { Time for serum-hCG normalization (days) }=48 \\
\text { Gestational age (day) }=35 \pm 21 \\
\text { Complication, } n=0 \\
\text { Success } \%=95.8\end{array}$ & High \\
\hline Li, 2012, [36] & China & 28 & $\begin{array}{l}\text { Before }=26,426 \\
\text { After }=\end{array}$ & $\begin{array}{l}\text { low-dose methotrexate- } \\
\text { curettage + Intramuscular }\end{array}$ & $\begin{array}{l}\text { Age (years) }=31.2 \pm 2.2 \\
\text { Complication, } n=0 \\
\text { Success\% }=96.2\end{array}$ & High \\
\hline Jurkovic, 2003, [37] & UK & 6 & $\begin{array}{l}\text { Before }=36,388 \\
\text { After }=25,000\end{array}$ & $\begin{array}{l}\text { local injection of } \\
25 \mathrm{mg} / \mathrm{m}^{2} \text { methotrexate }\end{array}$ & $\begin{array}{l}\text { Age (years) }=39.4 \pm 3.8 \\
\text { Complication, } n=2 \\
\text { Success\% } \% 66.7\end{array}$ & High \\
\hline Pirjani $-1,2015,[38]$ & Iran & 1 & & $\begin{array}{l}\text { Local MTX + Systemic } \\
\text { MTX }\end{array}$ & $\begin{array}{l}\text { Age }(\text { years })=35 \\
\text { Time for serum-hCG normalization (days) }=56 \\
\text { Gestational age }(\text { day) }=84 \\
\text { Fetal heart beat positive, } n=0 \\
\text { Complication, } n=0 \\
\text { Success } \%=92.9\end{array}$ & Medium \\
\hline Pirjani -2, 2015, [38] & Iran & 1 & & $\begin{array}{l}\text { Systemic MTX + Local } \\
\text { MTX }\end{array}$ & $\begin{array}{l}\text { Age (years) }=37 \\
\text { Time for serum-hCG normalization (days) }=35 \\
\text { Gestational age (day) }=35 \\
\text { Fetal heart beat positive, } n=1 \\
\text { Complication, } n=0 \\
\text { Success } \%=92.9\end{array}$ & Medium \\
\hline
\end{tabular}

For single-dose regimen, $50 \mathrm{mg}$ methotrexate per $\mathrm{m}^{2}$ of body and the level of $\beta$-hCG at days of 4 and 7 are measured, and should be decreased $15 \%$ or more; this followup is done weekly. In most women, the concentration of $\beta$ hCG naturally increases between days 1 and 4 , but, thereafter hormone level decreases. Each subsequent increase between days 4 and 7 is an indication for prescribing second dose (day 7) and is a determinant of decrease response of hormone level at day 11 . In case of failure in medicinal treatment, surgery is recommended [40]. 


\section{Funnel Plot of Standard Error by Mean}

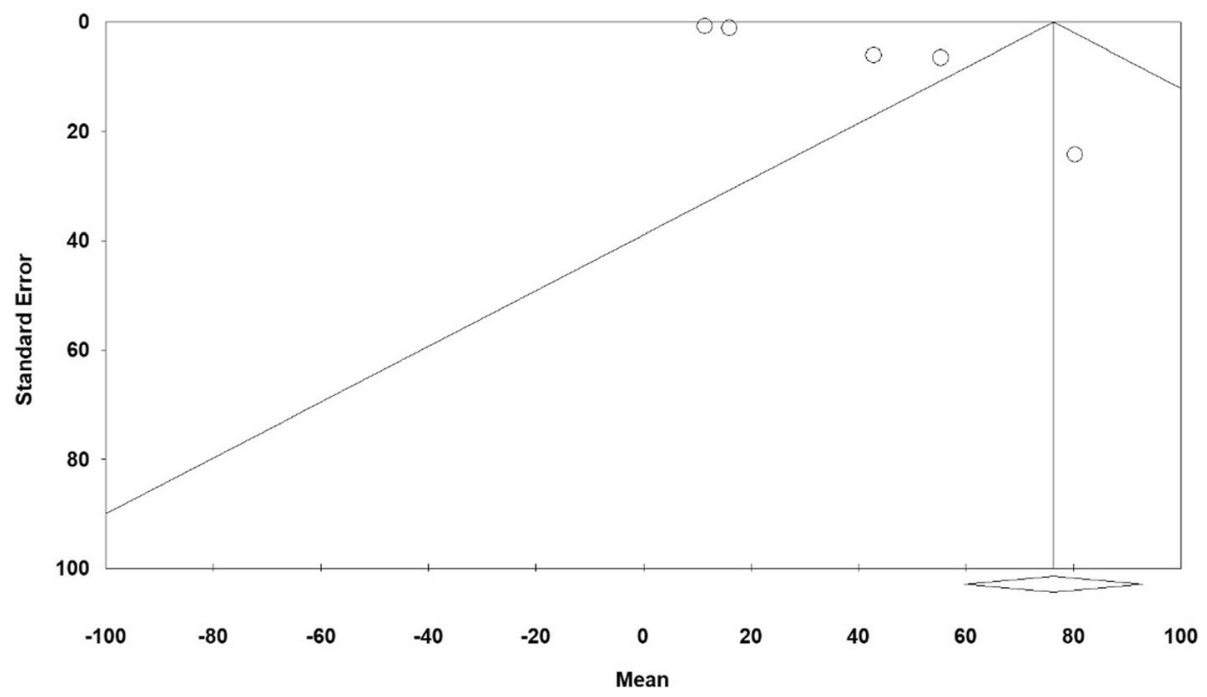

Fig. 2 Funnel plot of results related to Intraoperative blood loss (ml)

In double dose regimen, methotrexate is prescribed in days of 1 and 4 and serum level of $\beta$-hCG in days of 4-7 is measured. If the value decreases less than $15 \%$, the third dose should be prescribed and is assessed on day 11. If needed, the fourth dose can also be prescribed, and surgery is recommended if no response is given [41].

For multi-dose regimen, methotrexate $(1 \mathrm{mg} / \mathrm{kg}$ of muscular bodyweight) up to four doses are injected every other day to induce $15 \%$ or more decrease in the concentration of $\beta$-hCG and the level of hormone at days $1,3,5$ and 7 should be checked.

In case of lack of appropriate decline, surgery is recommended [41]. Soliman et al. (2006) found that in cases of $\beta$-hCG higher than 3000 to 4000 , the probability of surgery and failure of medicinal therapy is greater [42]. In the study by Lipscomb et al. (2005), level of $\beta$ hCG before the treatment is the most important factor in the failure of treatment [43].

The study by Eskandar (2007) reported that level of $\beta$ hCG as low as $2000 \mathrm{mlu} / \mathrm{ml}$ is a predictor of failure in medicinal treatment with a single dose of methotrexate [44].

The $\beta$-hCG level is an important predictor in the diagnosis of ectopic pregnancy and follow-up of response to treatment in patients. Mol reported that if $\beta$-hCG is less than $1500 \mathrm{IU} /$ Liter, it is better to use single-dose regimen, but if $\beta$-hCG is less than $3000 \mathrm{IU} /$ Liter, multi-dose regimen is better [45]. In two independent studies by Gabbur and Erdem on patients who underwent a singledose regimen of MTX, $\beta$-hCG level in the first day in a successful day is less than the group which needs second or more dose [46, 47].

Although, it was evident that by an increase in $\beta$-hCG, the probability of successful treatment decreases, there is no stable distinct level below which the treatment is more successful and the upper level to be relative inhibition for treatment [48]. In the study by Erdem, three out of 34 patients with failure in treatment had $\beta$-hCG greater than $4000 \mathrm{mlu} / \mathrm{ml}$ and two cases were with cardiac activity [47]. Menon showed on 503 patients that when $\beta$-hCG is greater than 5000 , the failure in treatment increases, and therefore, it is better to use MTX in these patients cautiously [48].

Markwitz showed that for 68 patients, when $\beta$-hCG is $1790 \mathrm{mlu} / \mathrm{ml}$, there is a risk of failure in treatment [49], and in the study by Gamzu, there was a $97 \%$ success in the treatment of $\beta$-hCG less than 2000 in comparison to $74 \%$ of success in the treatment of $\beta$-hCG higher than 2000 [50].

Since, in the current systematic review and metaanalysis, MTX leads to more than $15 \%$ reduction (17\%) in $\beta$-hCG level; therefore it can be considered as one successful pharmaceutical treatment in CSP. According to the findings of the current systematic review and meta-analysis, the success percentage was $90 \%$, and mean hospital stay (days) was also $11.7 \pm 1.2$ days. The rate of success in medicinal therapy of ectopic pregnancy by MTX is diverse, and about $71-100 \%$ [51].

In a research conducted in Iran (2000), out of $72 \mathrm{pa}-$ tients with ectopic pregnancy, 4 cases (5.6\%) were treated medicinally, which only one of them was 


\section{Funnel Plot of Standard Error by Mean}

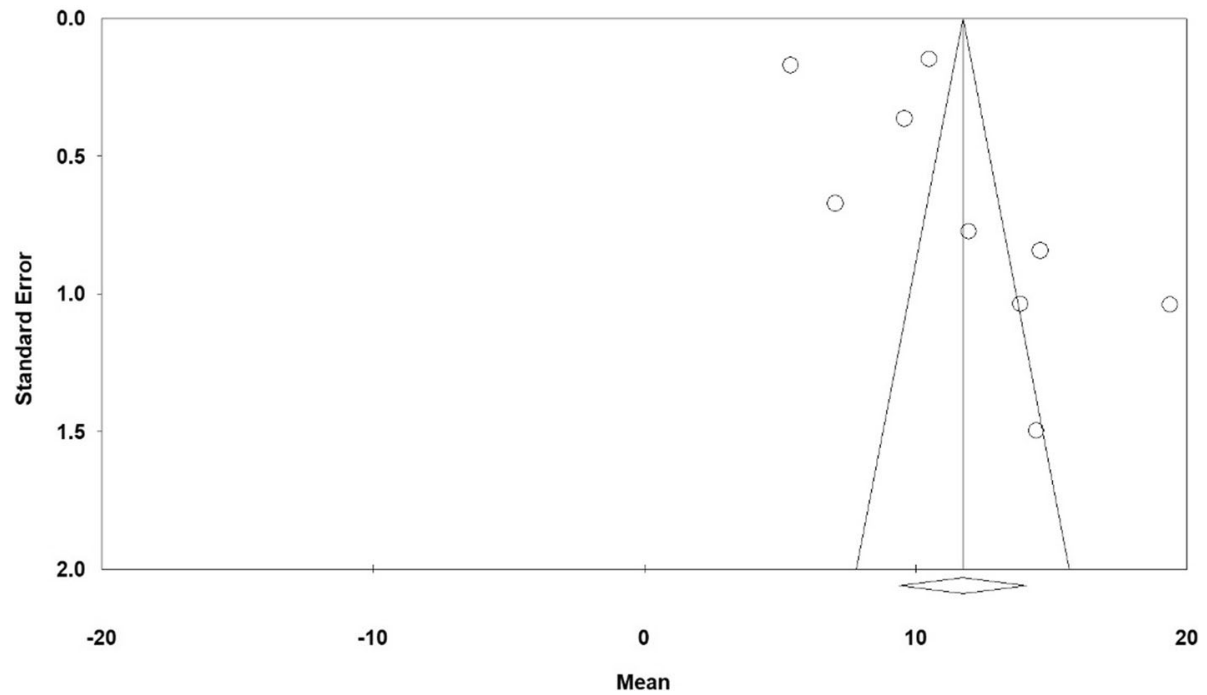

Fig. 3 Funnel plot of results related to Hospital stay (days)

successful, and three other patients need surgery [52], which was inconsistent with this study.

Its reason might be lack of probable follow-up of the patient and the rapid decision on performing surgery. In a retrospective study in Australia, out of 637 women diagnosed for ectopic pregnancy, 74 patients underwent medicinal treatment with MTX, which 14 cases were with failure (18.9\%), and out of 537 patients who underwent surgery, 30 patients (5.6\%) need reoperation [53].
From the year 1996 to 2001 in the USA, out of 1327 patients treated with MTX, 1181 patients (89\%) were treated successfully.

In a study in France (2003) on 137 women with nonruptured ectopic pregnancy, 70 patients received MTX intramuscularly, and 67 patients received injection intrahematosaplinx under sonographic control. Rate of success was $79.6 \%$, and topical use of MTX increases the probability of of success considerably [54].

\section{Funnel Plot of Standard Error by Mean}

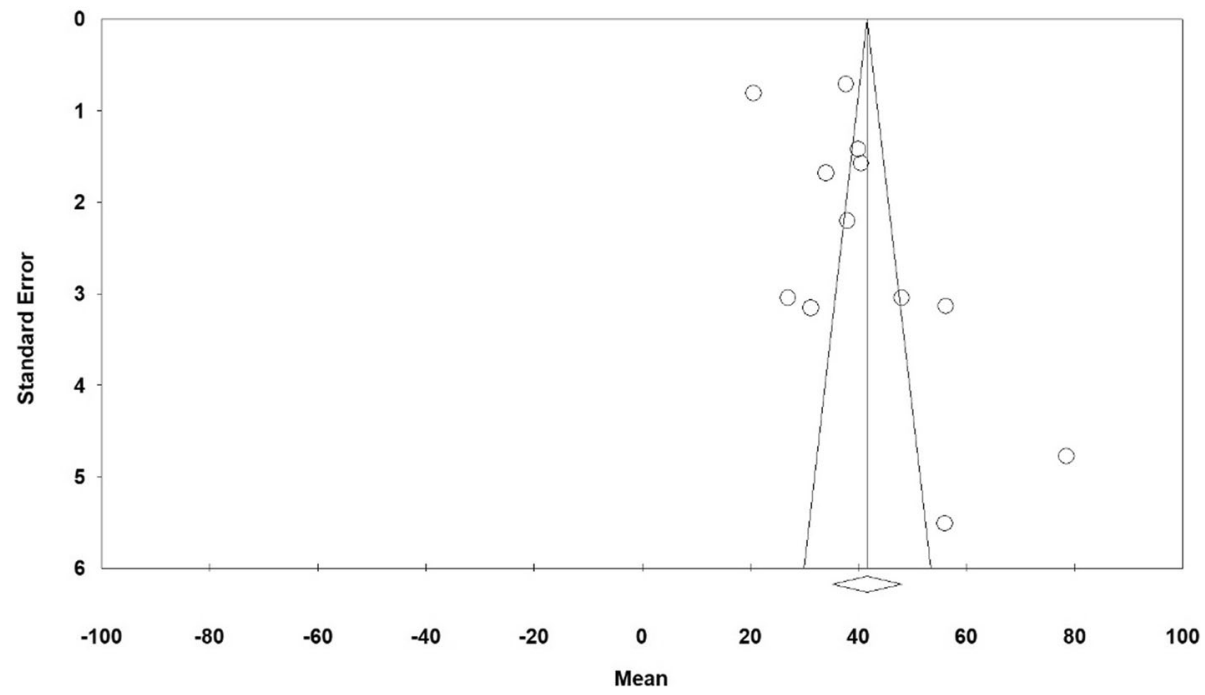

Fig. 4 Funnel plot of results related to Time for serum-hCG snormalisation (days) 


\section{Funnel Plot of Standard Error by Logit event rate}

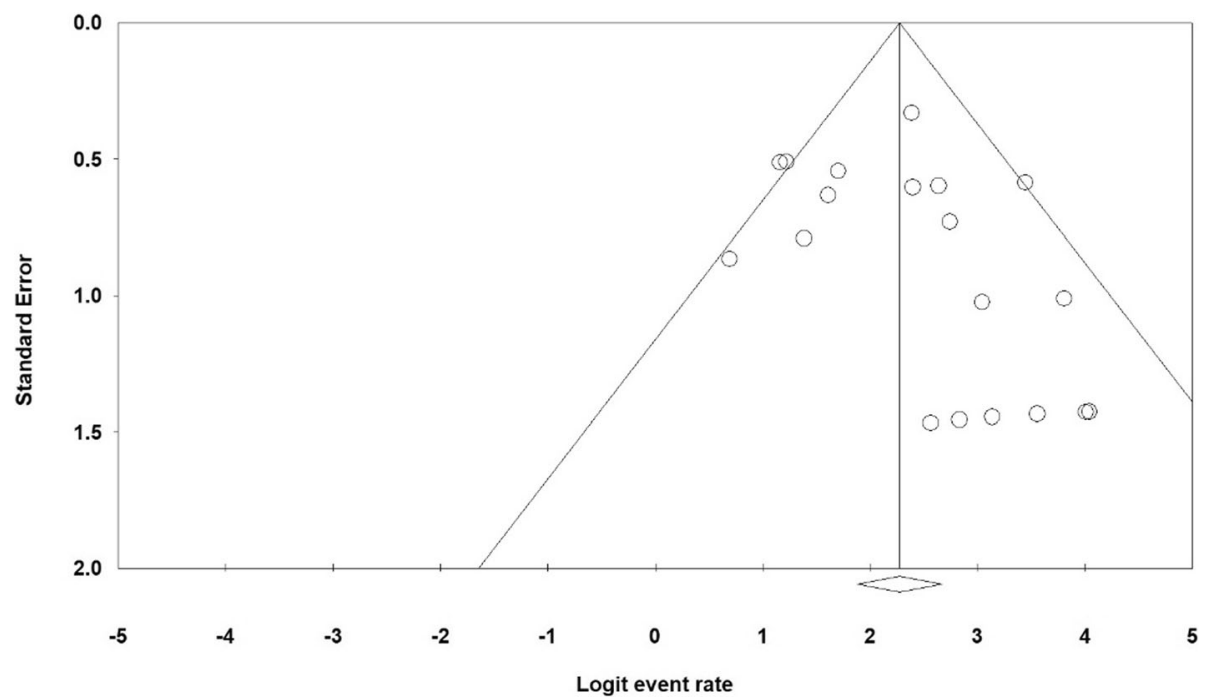

Fig. 5 Funnel plot of results related to percentage of success

In the study by Lewis et al. on 119 patients underwent medicinal therapy with MTX, 70\% of patients received a single dose, and $11 \%$ received double dose, which rate of success was reported as 79\% [55], which were in line with the current study. According to the results of the current systematic review and meta-analysis, complication achieved 9\%. MTX is with numerous side effects and in some cases is life-threatening. Gastrointestinal complications commonly occur by MTX, and renal toxification caused by the deposit of medication in renal tubules (particularly in acidic urine, patients with decreased volume and high serum level of MTX), and glumerol might occur. In addition, MTX by contraction of afferent artery and contraction of mesangial cells causes renal failure [56].

Hematologic complications, hepatic toxification, and pulmonary toxification are of other complications of MTX. Acute increase in serum transaminases from two to 20 times greater than standard value was observed in $80 \%$ of patients which is

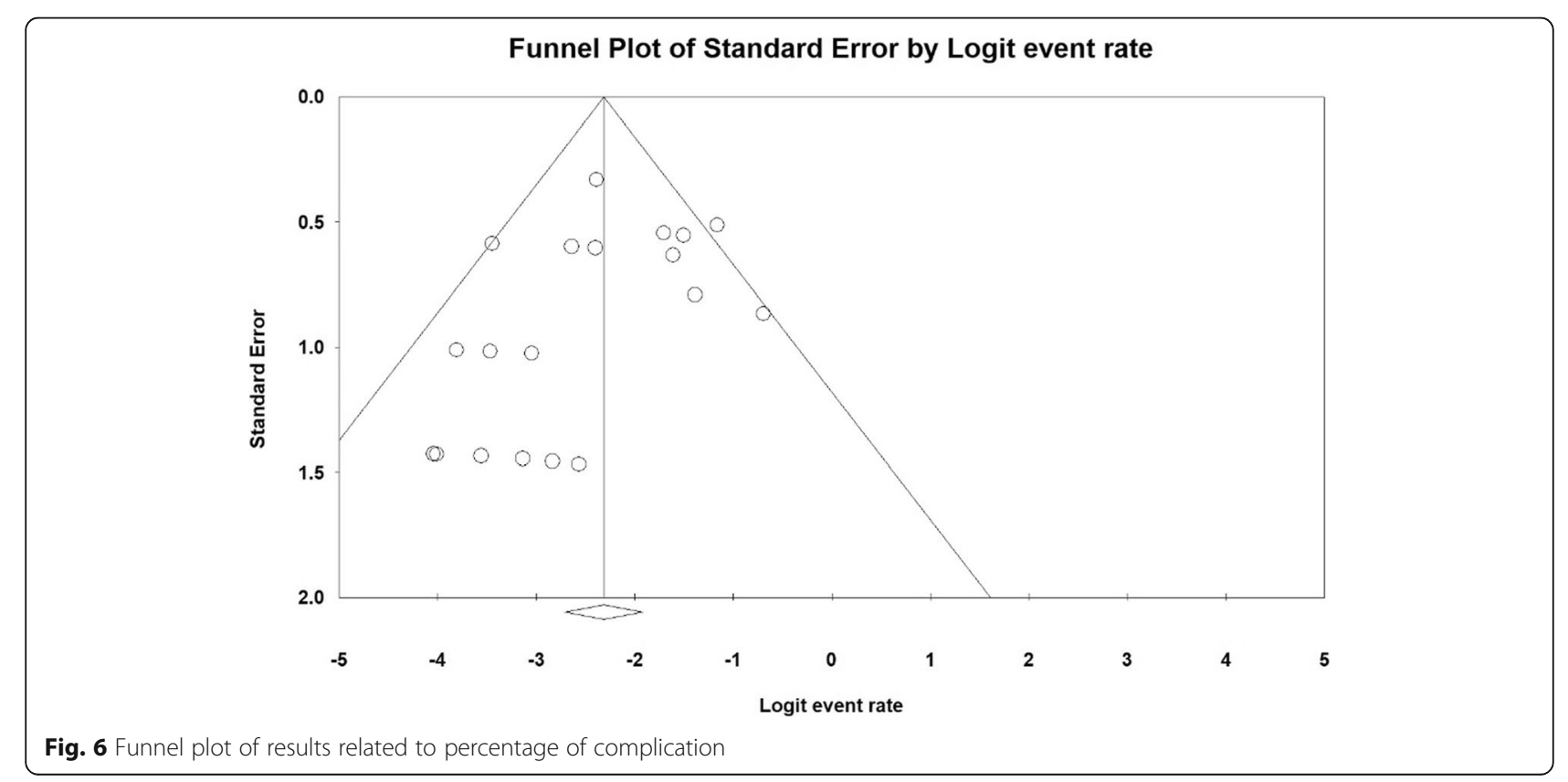




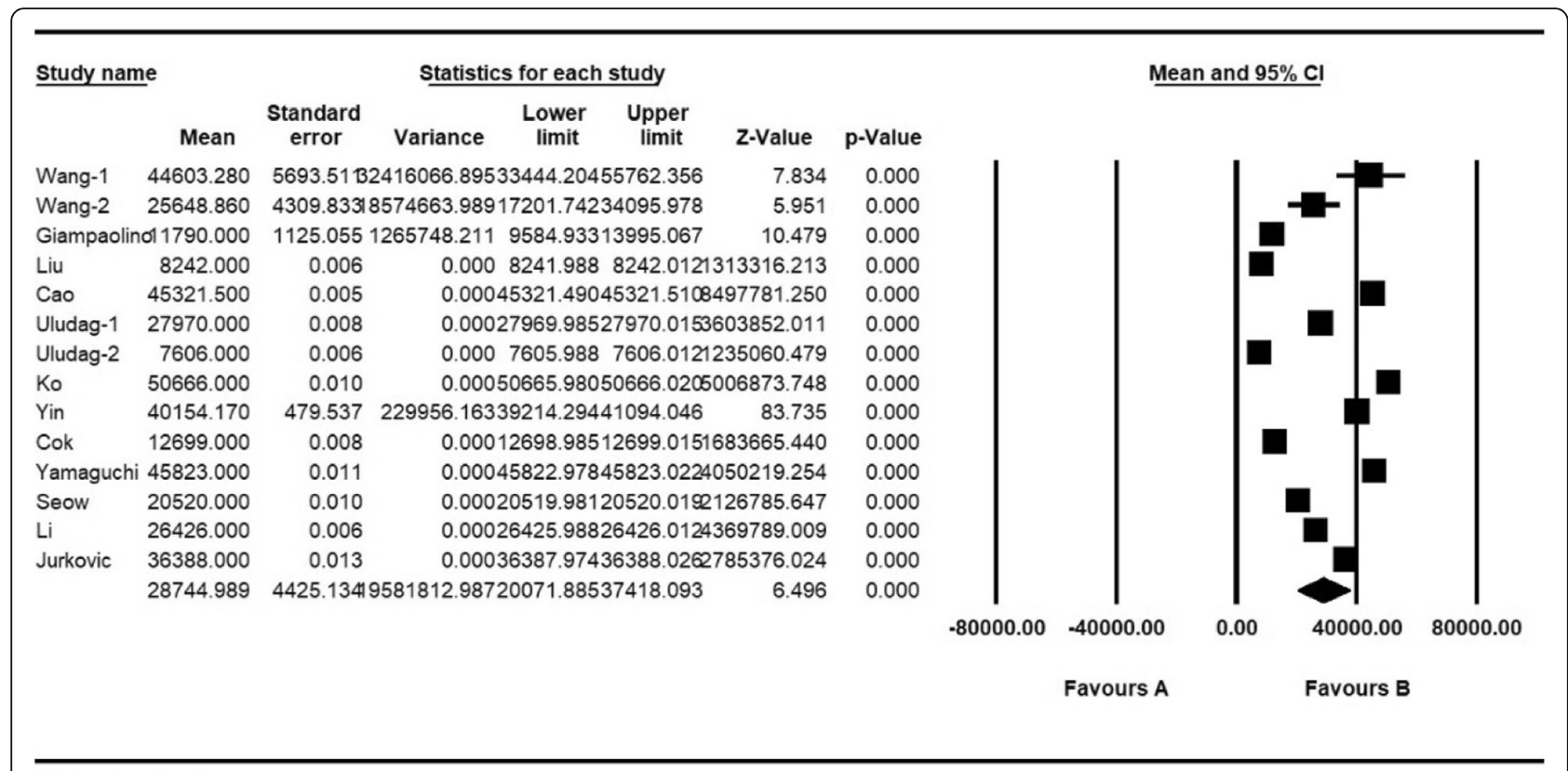

\section{Meta Analysis}

Fig. 7 mean level of $\beta$-hCG before the intervention and confidence interval of 95\%. The middle point of each line shows mean level of $\beta$-hCG before the intervention in each study, and the rhombic figure shows mean level of $\beta$-hCG before intervention for all the studies

relieved in one to two weeks spontaneously. If the value of alanine transferase does not reach to less than $180 \mathrm{IU} / \mathrm{L}$ at the initiation of following treatment course, a subsequent dose of MTX must be reduced or delayed [57].
Finally, due to current systematic review and metaanalysis and similar studies, it seems that treatment of CSP with MTX is an effective, low-risk, and low-cost method, and by considering this tip that most of the patients with CSP tend to preserve their fertility potential

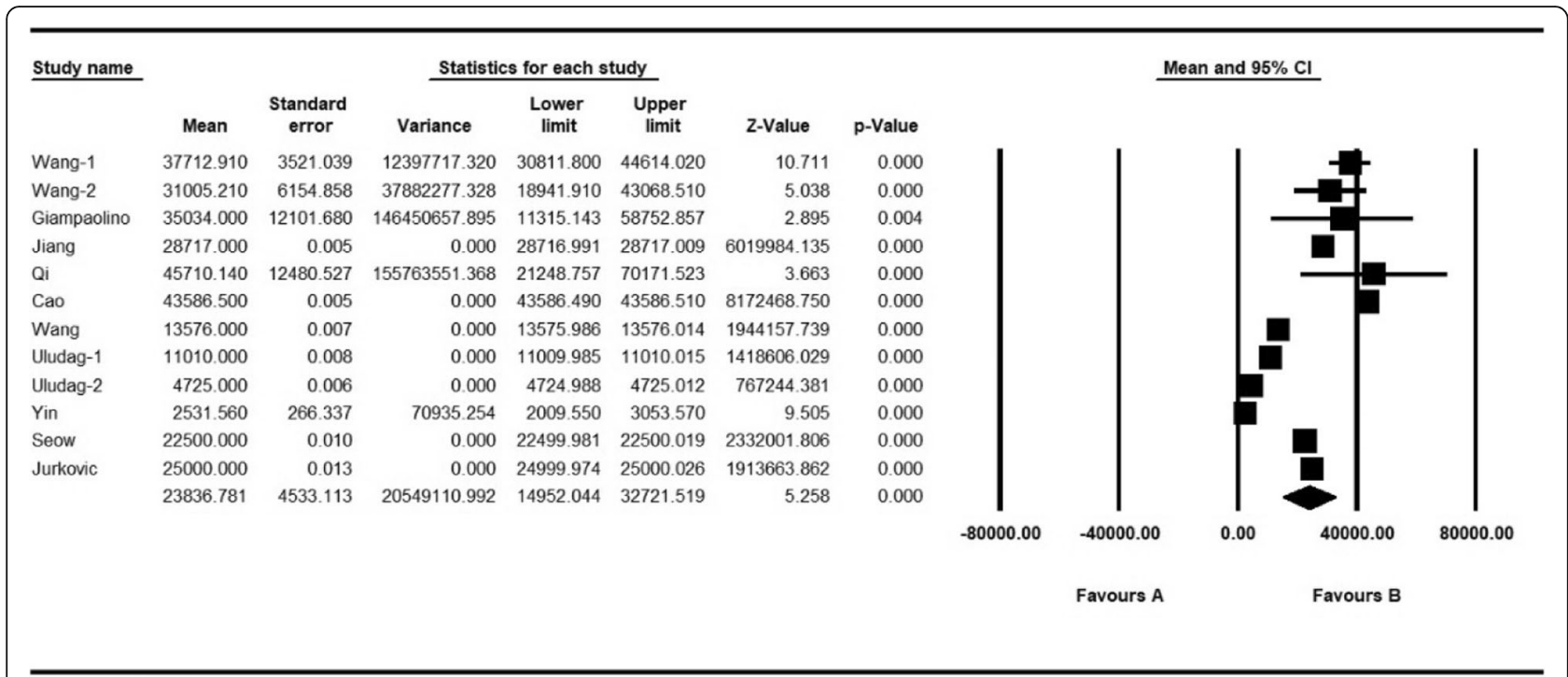

Meta Analysis

Fig. 8 Mean level of $\beta-h C G$ after the intervention and confidence interval of $95 \%$. The middle point of each line shows mean level of $\beta$-hCG before the intervention in each study, and the rhombic figure shows mean level of $\beta$-hCG before intervention for all the studies 


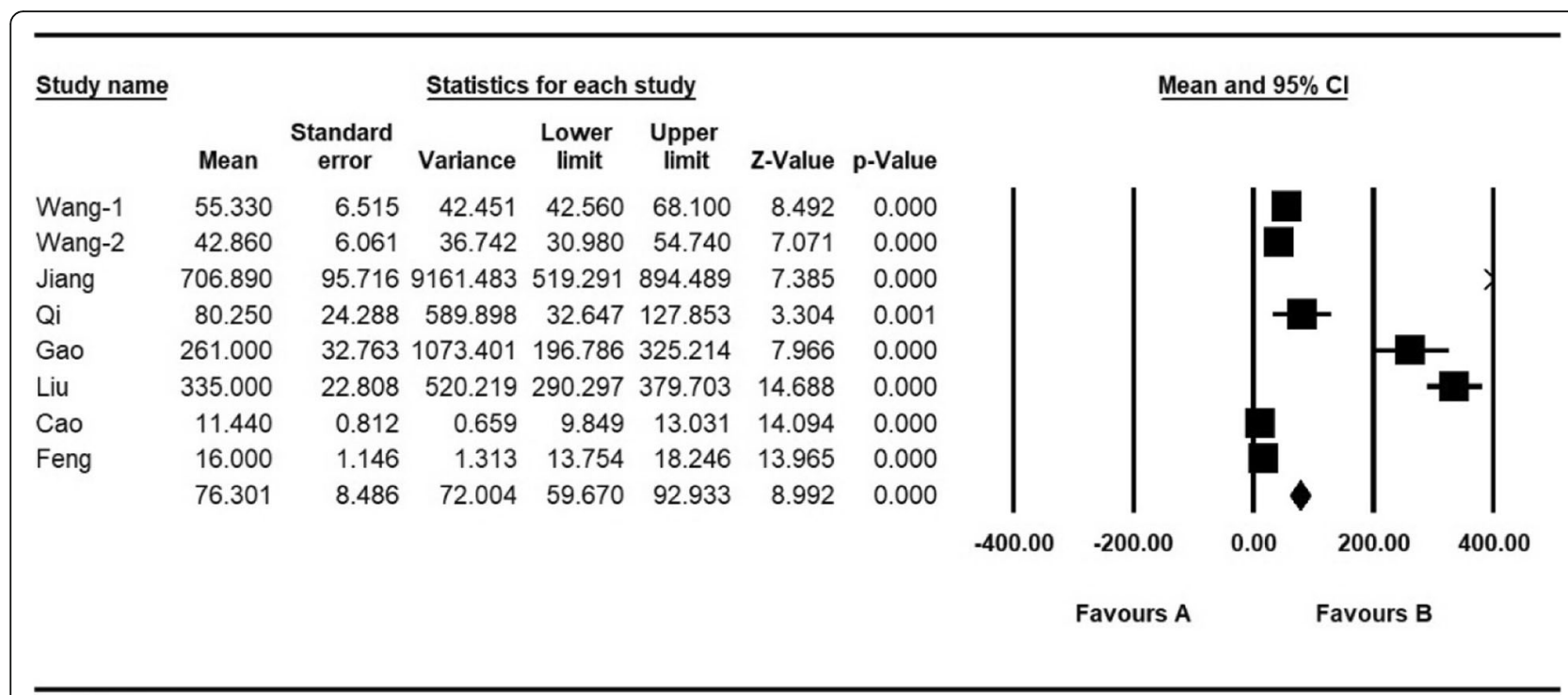

Meta Analysis

Fig. 9 Mean Intraoperative blood loss ( $\mathrm{ml}$ ) and confidence interval of 95\%. The middle point of each line shows mean Intraoperative blood loss $(\mathrm{ml})$ in each study, and the rhombic figure shows mean Intraoperative blood loss ( $\mathrm{ml}$ ) for all the studies

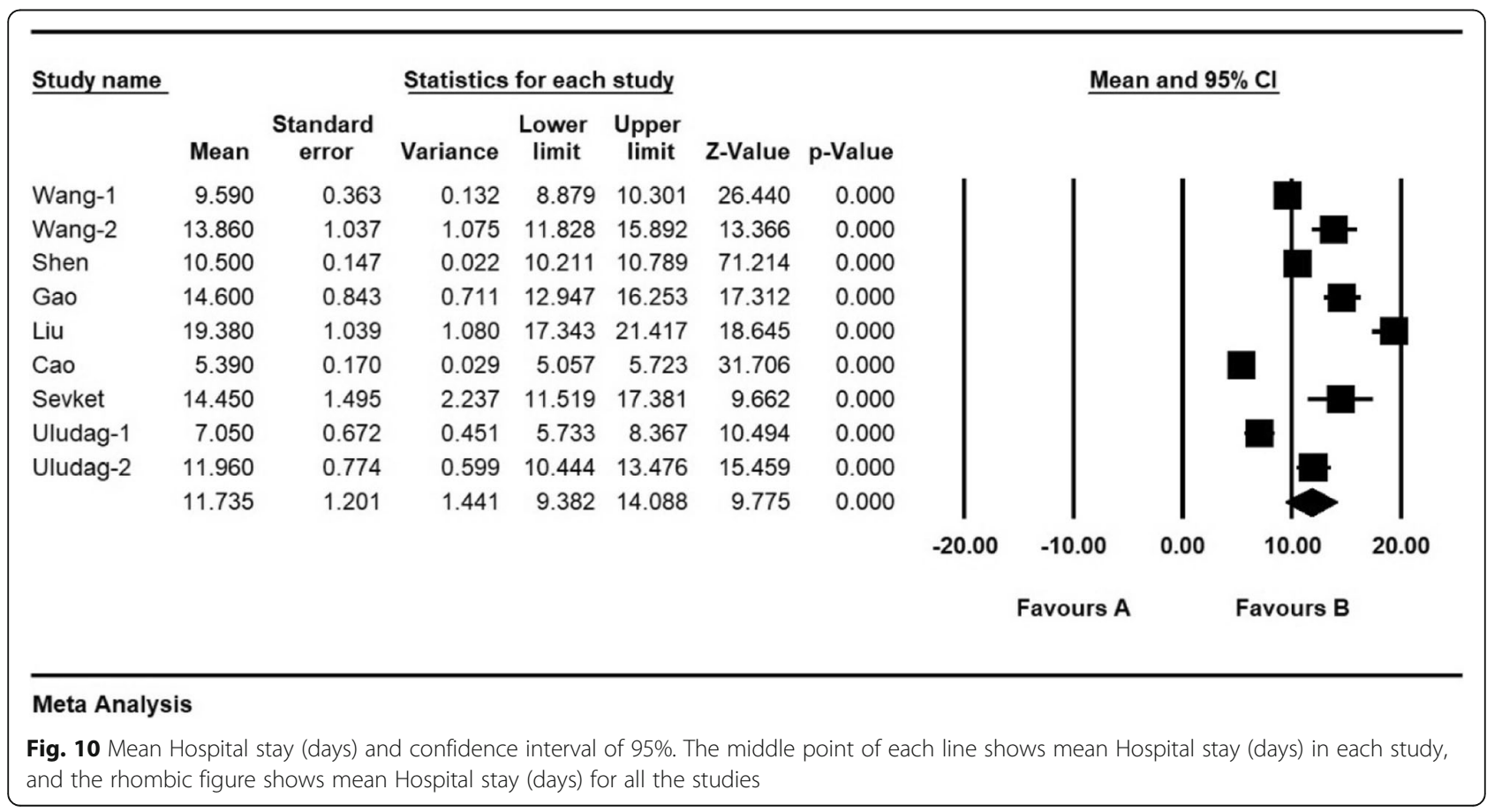




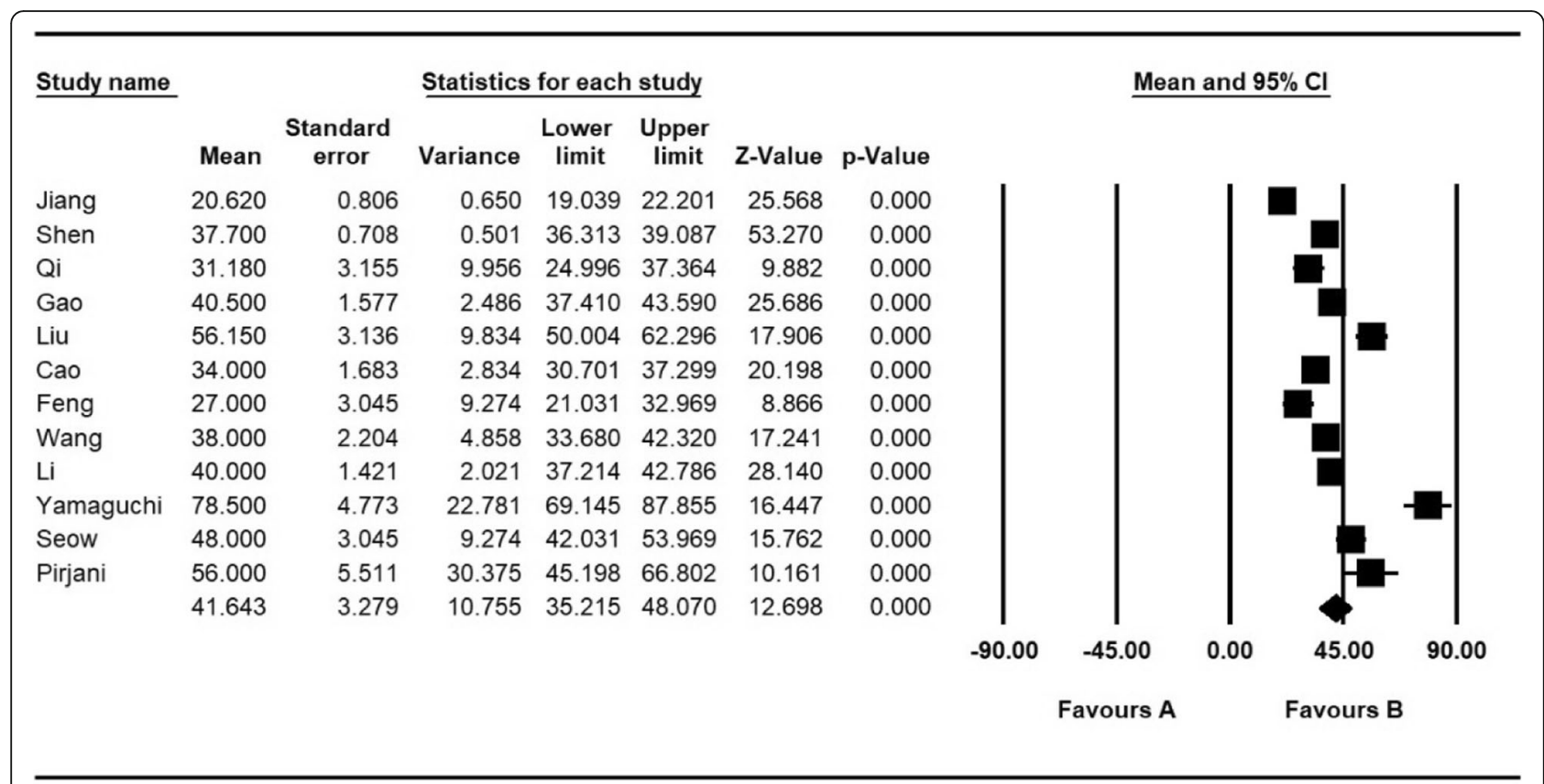

\section{Meta Analysis}

Fig. 11 Time for serum-hCG snormalisation (days) and confidence interval of 95\%. The middle point of each line shows Time for serum-hCG snormalisation (days) in each study, and the rhombic figure shows Time for serum-hCG snormalisation (days) for all the studies

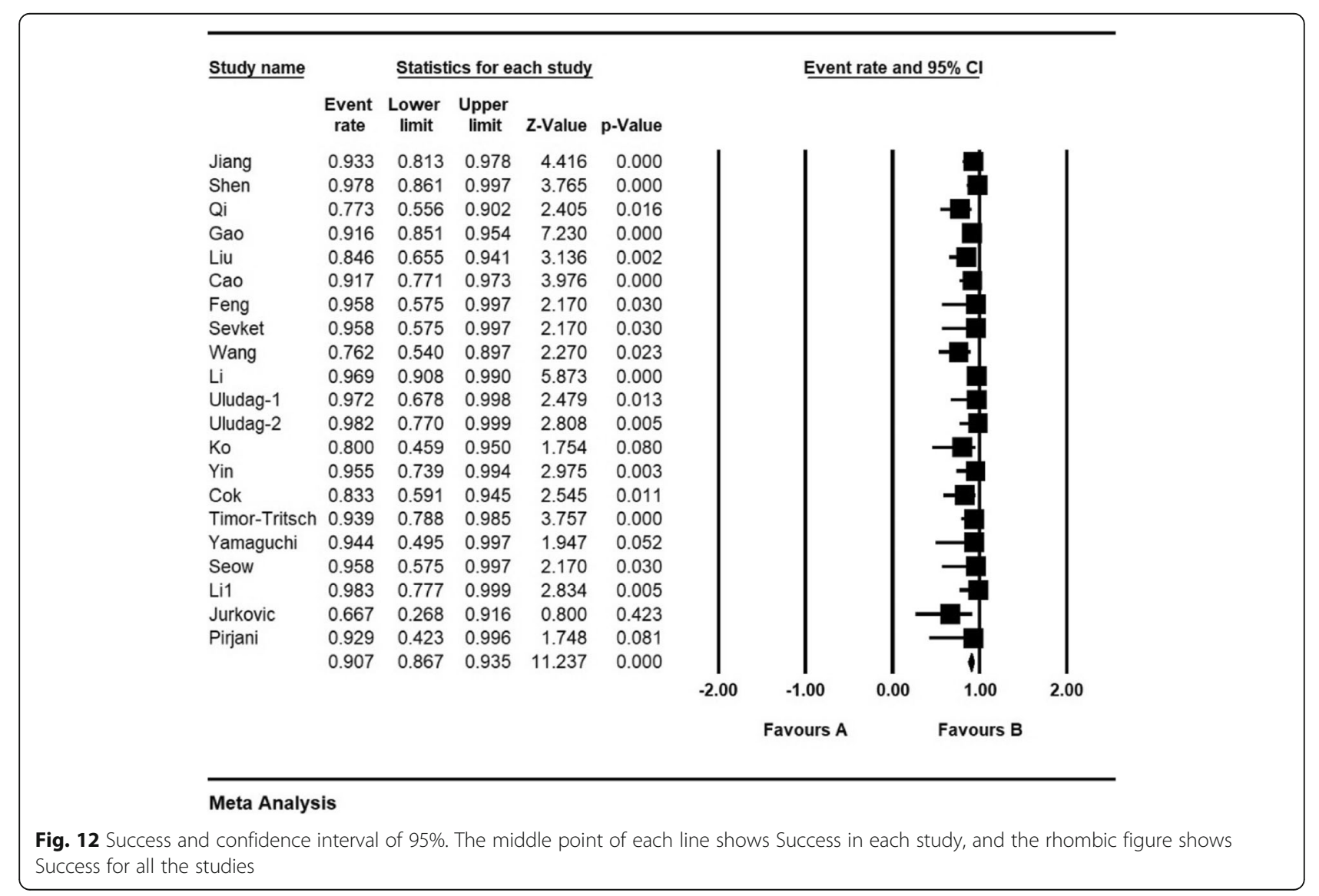




\begin{tabular}{|c|c|c|c|c|c|c|c|c|c|}
\hline \multirow[t]{2}{*}{ Study name } & \multicolumn{5}{|c|}{ Statistics for each study } & \multicolumn{4}{|c|}{ Event rate and $95 \% \mathrm{Cl}$} \\
\hline & $\begin{array}{c}\text { Event } \\
\text { rate }\end{array}$ & $\begin{array}{l}\text { Lower } \\
\text { limit }\end{array}$ & $\begin{array}{l}\text { Upper } \\
\text { limit }\end{array}$ & Z-Value & p-Value & & & & \\
\hline Jiang & 0.067 & 0.022 & 0.187 & -4.416 & 0.000 & & & & 1 \\
\hline Shen & 0.022 & 0.003 & 0.139 & -3.765 & 0.000 & & & & \\
\hline Qi & 0.182 & 0.070 & 0.396 & -2.721 & 0.007 & & & & \\
\hline Gao & 0.084 & 0.046 & 0.149 & -7.230 & 0.000 & & & & \\
\hline Liu & 0.154 & 0.059 & 0.345 & -3.136 & 0.002 & & & & \\
\hline $\mathrm{CaO}$ & 0.083 & 0.027 & 0.229 & -3.976 & 0.000 & & & & \\
\hline Feng & 0.042 & 0.003 & 0.425 & -2.170 & 0.030 & & & & \\
\hline Sevket & 0.042 & 0.003 & 0.425 & -2.170 & 0.030 & & & & \\
\hline Wang & 0.238 & 0.103 & 0.460 & -2.270 & 0.023 & & & & \\
\hline $\mathrm{Li}$ & 0.031 & 0.010 & 0.092 & -5.873 & 0.000 & & & & \\
\hline Uludag-1 & 0.028 & 0.002 & 0.322 & -2.479 & 0.013 & & & & \\
\hline Uludag-2 & 0.018 & 0.001 & 0.230 & -2.808 & 0.005 & & & & \\
\hline Ko & 0.200 & 0.050 & 0.541 & -1.754 & 0.080 & & & & \\
\hline Yin & 0.045 & 0.006 & 0.261 & -2.975 & 0.003 & & & & \\
\hline Cok & 0.167 & 0.055 & 0.409 & -2.545 & 0.011 & & & & \\
\hline Timor-Tritsch & 0.030 & 0.004 & 0.186 & -3.413 & 0.001 & & & & \\
\hline Yamaguchi & 0.056 & 0.003 & 0.505 & -1.947 & 0.052 & & & & \\
\hline Seow & 0.042 & 0.003 & 0.425 & -2.170 & 0.030 & & & & \\
\hline Li1 & 0.017 & 0.001 & 0.223 & -2.834 & 0.005 & & & & \\
\hline Jurkovic & 0.333 & 0.084 & 0.732 & -0.800 & 0.423 & & & & \\
\hline \multirow[t]{4}{*}{ Pirjani } & 0.071 & 0.004 & 0.577 & -1.748 & 0.081 & & & & \\
\hline & 0.090 & 0.063 & 0.128 & -11.487 & 0.000 & & & $\boldsymbol{\gamma}$ & \\
\hline & & & & & & -1.00 & -0.50 & 0.00 & 1.00 \\
\hline & & & & & & & Favours A & Favour & \\
\hline
\end{tabular}

Meta Analysis

Fig. 13 Complication and confidence interval of 95\%. The middle point of each line shows Complication in each study, and the rhombic figure shows Complication for all the studies

in future, it should be tried to treat these patients with a medicinal method.

Therefore, it is recommended that there should be a change in attitude and behaviour of co-workers to face patients with ectopic pregnancy. First, in order to early diagnosis and second the application of medicinal therapy in most suitable cases of surgical treatment, and surgical treatment should be done only in cases of impossible medicinal therapy or in lack of access to follow the patient.

\section{Conclusion}

The results of the current study show that methotrexate significantly reduces $\beta$-hCG levels and can be effective in treating caesarean scar pregnancy and its complications.

\section{Abbreviations}

SID: Scientific Information Database; CONSORT: Consolidated Standards of Reporting Trials; PRISMA: Preferred Reporting Items for Systematic Reviews and Meta-Analysis

\section{Acknowledgements}

The authors thank the Student Research Committee, Kermanshah University of Medical Sciences, Kermanshah, Iran.

\section{Authors' contributions}

AN and NS contributed to the design, MM statistical analysis, participated in most of the study steps. MK and SHSH prepared the manuscript. All authors have read and approved the content of the manuscript.

Funding

By Student Research Committee of Kermanshah University of Medical Sciences. Research and Technology, Kermanshah University of Medical Sciences (3009512).

Availability of data and materials

Datasets are available through the corresponding author upon reasonable request.

Ethics approval and consent to participate

Ethics approval by the ethics committee of deputy for Research and Technology, Kermanshah University of Medical Sciences (IR) (3009512).

\section{Consent for publication}

Not applicable.

\section{Competing interests}

The authors declare that they have no conflict of interest.

\section{Author details}

'Department of Biostatistics, School of Health, Kermanshah University of Medical Sciences, Kermanshah, Iran. ${ }^{2}$ Sleep Disorders Research Center, Kermanshah University of Medical Sciences, Kermanshah, Iran. ${ }^{3}$ Student Research Committee, Kermanshah University of Medical Sciences, Kermanshah, Iran. ${ }^{4}$ Department of Biology, Faculty of Science, Universiti Putra Malaysia, Serdang, Selangor, Malaysia. ${ }^{5}$ Department of Obstetrics and Gynecology, School of Medicine, Kermanshah University of Medical Sciences, 
Kermanshah, Iran. ${ }^{6}$ Department of Nursing, School of Nursing and Midwifery, Kermanshah University of Medical Sciences, Kermanshah, Iran.

\section{Received: 23 April 2020 Accepted: 30 October 2020} Published online: 09 November 2020

\section{References}

1. Della-Giustina D, Denny M. Ectopic pregnancy. Emerg Med Clin North Am. 2003 Aug;21(3):565-84.

2. Benton T. Pain management is part of advance directives discussion. Am Fam Physician. 2006;73(8):1331.

3. Mettler L, Sodhi B, Schollmeyer T, Mangeshikar P. Ectopic pregnancy treatment by laparoscopy, a short glimpse. Minim Invasive Ther Allied Technol. 2006;15(5):305-10

4. Nieuwkerk PT, Hajenius PJ, Van der Veen F, Ankum WM, Wijker W, Bossuyt PM. Systemic methotrexate therapy versus laparoscopic salpingostomy in tubal pregnancy. Part II. Patient preferences for systemic methotrexate. Fertil Steril. 1998;70(3):518-22.

5. Rotas MA, Haberman S, Levgur M. Cesarean scar ectopic pregnancies: etiology, diagnosis, and management. Obstet Gynecol. 2006;107(6):1373-81.

6. Seow KM, Huang LW, Lin YH, Yan-Sheng Lin M, Tsai YL, Hwang JL. Cesarean scar pregnancy: issues in management. Ultrasound Obstet Gynecol. 2004; 23(3):247-53.

7. Nankali A, Ataee M, Shahlazadeh H, Daeichin S. Surgical management of the cesarean scar ectopic pregnancy: a case report. Case Rep Obstet Gynecol. 2013;2013:1-3.

8. Sowter MC, Farquhar CM, Gudex G. An economic evaluation of single dose systemic methotrexate and laparoscopic surgery for the treatment of unruptured ectopic pregnancy. BJOG Int J Obstet Gynaecol. 2001;108(2): 204-11.

9. Rozenberg P, Chevret S, Camus E, Tayrac R d, Garbin O, Poncheville L d, Coiffic J, Lucot JP, Goueff FL, Tardif D. Medical treatment of ectopic pregnancies: a srandomised clinical trial comparing methotrexatemifepristone and methotrexate-placebo. Hum Reprod. 2003;18(9):1802-8.

10. Hajenius PJ, Mol F, Mol BWJ, Bossuyt PM, Ankum WM, Van der Veen F. Interventions for tubal ectopic pregnancy. Cochrane Database Syst Rev. 2007:1.

11. Corsan GH, Karacan M, Qasim S, Bohrer MK, Ransom MX, Kemmann E. Identification of hormonal parameters for successful systemic single-dose methotrexate therapy in ectopic pregnancy. Hum Reprod. 1995;10(10):2719-22.

12. Ransom MX, Garcia AJ, Bohrer M, Corsan GH, Kemmann E. Serum progesterone as a predictor of methotrexate success in the treatment of ectopic pregnancy. Obstet Gynecol. 1994;83(6):1033-7.

13. Perdu M, Camus E, Rozenberg P, Goffinet F, Chastang C, Philippe H-J, Nisand I. Treating ectopic pregnancy with the combination of mifepristone and methotrexate: a phase II snonrandomised study. Am J Obstet Gynecol. 1998;179(3):640-3.

14. Stika CS, Anderson L, Frederiksen MC. Single-dose methotrexate for the treatment of ectopic pregnancy: northwestern memorial hospital three-year experience. Am J Obstet Gynecol. 1996;174(6):1840-8.

15. Schulz KF, Altman DG, Moher D. CONSORT 2010 statement: updated guidelines for reporting parallel group randomised trials. BMC Med. 2010; $8(1): 18$.

16. Wang $\mathrm{S}$, Beejadhursing R, Ma X, Li Y. Management of Caesarean scar pregnancy with or without methotrexate before curettage: human chorionic gonadotropin trends and patient outcomes. BMC Pregnancy Child. 2018;18(1):289.

17. Giampaolino, P., N. De Rosa, I. Morra, A. Bertrando, A. Di Spiezio Sardo, B. Zizolfi, C. Ferrara, L. Della Corte and G. Bifulco (2018). "Management of cesarean scar pregnancy: a single-institution retrospective review." BioMed research international 2018.

18. Jiang T, Liu G, Huang L, Ma H, Zhang S. Methotrexate therapy followed by suction curettage followed by Foley tamponade for caesarean scar pregnancy. Eur J Obstet Gynecol Reprod Biol. 2011;156(2):209-11.

19. Shen, L., A. Tan, H. Zhu, C. Guo, D. Liu and W. Huang (2012). "Bilateral uterine artery schemoembolisation with methotrexate for cesarean scar pregnancy". Am J Obstet Gynecol 207(5): 386. e381-386. e386.

20. Qi F, Zhou W, Wang M-F, Chai Z-Y, Zheng L-Z. Uterine artery sembolisation with and without local methotrexate infusion for the treatment of cesarean scar pregnancy. Taiwanese J Obstet Gynecol. 2015;54(4):376-80.
21. Gao L, Huang Z, Gao J, Mai H, Zhang Y, Wang X. Uterine artery sembolisation followed by dilation and curettage within 24 hours compared with systemic methotrexate for cesarean scar pregnancy. Int J Gynecol Obstet. 2014;127(2):147-51.

22. Liu W, Shen L, Wang $Q$, Wang W, Sun Z. Uterine artery sembolisation combined with curettage vs. methotrexate plus curettage for cesarean scar pregnancy. Arch Gynecol Obstet. 2016;294(1):71-6.

23. Cao G-S, Liu R-Q, Liu Y-Y, Liu J-W, Li L-P, Zhang Q, Cao H-C, Li T-X. Menstruation recovery in scar pregnancy patients undergoing UAE and curettage and its influencing factors. Medicine. 2018:97(11):e9584.

24. Feng Y, Chen S, Li C, Zhang X, Duan H, Sooranna S, Johnson MR, Li J. Curettage after uterine artery sembolisation combined with methotrexate treatment for caesarean scar pregnancy. Exp Ther Med. 2016;12(3):1469-75.

25. Sevket O, Keskin S, Ates S, Molla T, Dansuk R, Yazicioglu HF, Yucel O. Is methotrexate administration needed for the treatment of caesarean section scar pregnancy in addition to suction curettage? Eur I Contracept Reprod Health Care. 2014;19(2):128-33.

26. Fadhlaoui, A., M. Khrouf, K. Khémiri, K. Nouira, A. Chaker and F. Zhioua (2012). "Successful conservative treatment of a cesarean scar pregnancy with systemically administered methotrexate and subsequent dilatation and curettage: a case report". Case reports in obstetrics and gynecology 2012.

27. Wang J-H, Xu K-H, Lin J, Xu J-Y, Wu R-J. Methotrexate therapy for cesarean section scar pregnancy with and without suction curettage. Fertil Steril. 2009;92(4):1208-13.

28. Abdelazim IA, Abu-Faza M, Zhurabekova G, Shikanova S, Kanshaiym S, Karimova B, Sarsembayev M, Starchenko T. Successful pregnancy outcome immediately after methotrexate treatment for cesarean section scar pregnancy. Gynecol Minimally Invasive Ther. 2019;8(4):185.

29. Uludag SZ, Kutuk MS, Ak M, Ozgun MT, Dolanbay M, Aygen EM, Sahin Y. Comparison of systemic and local methotrexate treatments in cesarean scar pregnancies: time to change conventional treatment and follow-up protocols. Eur J Obstet Gynecol Reprod Biol. 2016;206:131-5.

30. Ko JK, Li RH, Cheung VY. Caesarean scar pregnancy: a 10-year experience. Aust N Z J Obstet Gynaecol. 2015;55(1):64-9.

31. Yin X-H, Yang S-Z, Wang Z-Q, Jia H-Y, Shi M. Injection of MTX for the treatment of cesarean scar pregnancy: comparison between different methods. Int J Clin Exp Med. 2014;7(7):1867.

32. Cok T, Kalayci H, Ozdemir H, Haydardedeoglu B, Parlakgumus AH, Tarim E. Transvaginal ultrasound-guided local methotrexate administration as the first-line treatment for cesarean scar pregnancy: follow-up of 18 cases. J Obstet Gynaecol Res. 2015;41(5):803-8.

33. Timor-Tritsch IE, Khatib N, Monteagudo A, Ramos J, Berg R, Kovacs S. Cesarean scar pregnancies: experience of 60 cases. J Ultrasound Med. 2015; 34(4):601-10.

34. Yamaguchi M, Honda R, Uchino K, Tashiro H, Ohba T, Katabuchi H. Transvaginal methotrexate injection for the treatment of cesarean scar pregnancy: efficacy and subsequent fecundity. J Minim Invasive Gynecol. 2014;21(5):877-83.

35. Seow K-M, Wang P-H, Huang L-W, Hwang J-L. Transvaginal sono-guided aspiration of gestational sac concurrent with a local methotrexate injection for the treatment of unruptured cesarean scar pregnancy. Arch Gynecol Obstet. 2013;288(2):361-6.

36. Li N, Zhu F, Fu S, Shi X. Transvaginal ultrasound-guided embryo aspiration plus local administration of low-dose methotrexate for caesarean scar pregnancy. Ultrasound Med Biol. 2012;38(2):209-13.

37. Jurkovic D, Hillaby K, Woelfer B, Lawrence A, Salim R, Elson C. First-trimester diagnosis and management of pregnancies implanted into the lower uterine segment cesarean section scar. Ultrasound Obstet Gynecol. 2003;21(3):220-7.

38. Pirjani R, Bayanni L, Shirazi M. Successful local and systemic medical treatment of cesarean scar pregnancy and a subsequent term pregnancy after treatment: a case series, Iran. J Reprod Med. 2015;13(7):445-50

39. Fritz, M. A. and L. Speroff (2012). Clinical gynecologic endocrinology and infertility, lippincott Williams \& wilkins.

40. Lipscomb GH, Stovall TG, Ling FW. Nonsurgical treatment of ectopic pregnancy. N Engl J Med. 2000;343(18):1325-9.

41. Barnhart KT, Gosman G, Ashby R, Sammel M. The medical management of ectopic pregnancy: a meta-analysis comparing "single dose" and "multidose" regimens. Obstet Gynecol. 2003;101(4):778-84.

42. Soliman KB, Saleh NM, Omran AA. Safety and efficacy of systemic methotrexate in the treatment of unruptured tubal pregnancy. Saudi Med J. 2006;27(7):1005 
43. Lipscomb GH, Givens VM, Meyer NL, Bran D. Comparison of multidose and single-dose methotrexate protocols for the treatment of ectopic pregnancy. Am J Obstet Gynecol. 2005;192(6):1844-7.

44. Eskandar M. Single dose methotrexate for treatment of ectopic pregnancy: risk factors for treatment failure. Middle East Fertil Soc J. 2007;12(1):57.

45. Mol F, Mol B, Ankum W, Van der Veen F, Hajenius P. Current evidence on surgery, systemic methotrexate and expectant management in the treatment of tubal ectopic pregnancy: a systematic review and metaanalysis. Hum Reprod Update. 2008;14(4):309-19.

46. Gabbur N, Sherer DM, Hellmann M, Abdelmalek E, Phillip P, Abulafia O. Do serum beta-human chorionic gonadotropin levels on day 4 following methotrexate treatment of patients with ectopic pregnancy predict successful single-dose therapy? Am J Perinatol. 2006;23(03):193-6.

47. Erdem M, Erdem A, Arslan M, Öç A, Biberoğlu K, Gürsoy R. Single-dose methotrexate for the treatment of unruptured ectopic pregnancy. Arch Gynecol Obstet. 2004;270(4):201-4.

48. Menon S, Colins J, Barnhart KT. Establishing a human chorionic gonadotropin cutoff to guide methotrexate treatment of ectopic pregnancy: a systematic review. Fertil Steril. 2007;87(3):481-4.

49. Nowak-Markwitz E, Michalak M, Olejnik M, Spaczynski M. Cutoff value of human chorionic gonadotropin in relation to the number of methotrexate cycles in the successful treatment of ectopic pregnancy. Fertil Steril. 2009; 92(4):1203-7.

50. Gamzu R, Almog B, Levin Y, Avni A, Jaffa A, Lessing JB, Baram A. Efficacy of methotrexate treatment in extrauterine pregnancies defined by stable or increasing human chorionic gonadotropin concentrations. Fertil Steril. 2002; 77(4):761-5.

51. Luciano AA, Roy G, Solima E. Ectopic pregnancy: from surgical emergency to medical management. Annals of the New York Academy of Sciences. 2001;943(1):235-54.

52. Marion LL, Rodney Meeks G. Ectopic pregnancy: History, incidence, epidemiology, and risk factors. Clin Obstet Gynecol. 2012;55(2):376-86.

53. Pietrzak Z. Ectopic pregnancy. II. Evaluation of the clinical value of a diagnostic algorithm for ectopic pregnancy. Ginekologia Polska. 2001;72(1): 7-11.

54. Nazac A, Gervaise A, Bouyer J, De Tayrac R, Capella-Allouc S, Fernandez H. Predictors of success in methotrexate treatment of women with unruptured tubal pregnancies. Ultrasound in Obstetrics and Gynecology: The Official Journal of the International Society of Ultrasound in Obstetrics and Gynecology. 2003;21(2):181-5.

55. Lewis-Bliehall C, Rogers RG, Kammerer-Doak DN, Conway SC, Amaya C, Byrn F. Medical vs. Surgical treatment of ectopic pregnancy. The University of New Mexico's six-year experience. Int J Reprod Med. 2001; 46(11):983-8.

56. Howard SC, McCormick J, Pui CHH, Buddington RK, Donald Harvey R. Preventing and Managing Toxicities of High-Dose Methotrexate. Oncologist. 2016;21(12):1471-82.

57. Bath RK, Brar NK, Forouhar FA, Wu GY. A review of methotrexate-associated hepatotoxicity. J Dig Dis. 2014;15(10):517-24.

\section{Publisher's Note}

Springer Nature remains neutral with regard to jurisdictional claims in published maps and institutional affiliations.

Ready to submit your research? Choose BMC and benefit from:

- fast, convenient online submission

- thorough peer review by experienced researchers in your field

- rapid publication on acceptance

- support for research data, including large and complex data types

- gold Open Access which fosters wider collaboration and increased citations

- maximum visibility for your research: over $100 \mathrm{M}$ website views per year

At BMC, research is always in progress.

Learn more biomedcentral.com/submissions 